\section{DREAM-TIME LAW: Australian Aborigine Philosophy}

\author{
MICHAEL W. FOX \\ Humane Society of the United States
}

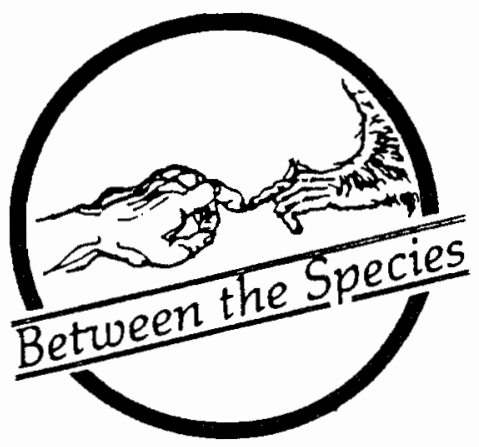

with others and with the reeling-full field of sentient life: the Buddha-biofield.

This state is more than one of imaginative projection or psychotic delusion because the naked (undefended) ego is at once connected empathetically with the entire field of $\infty$-inherent sentience and interdependent being. We must want to feel, to feel the fullness of life's joys and pains in order to live fully. But we are so often afraid of life's pains that we deny the pain we should experience when we see or know of others' suffering, be they other humans or fellow animals and plants, and other living bodies that we call mountains, deserts, forests, savannas, jungles, oceans, and rivers, and which we all surely love as we love our own. To know the Body of Christ we must feel as the Earth feels and knows. It is not what one thinks that makes a person, but what one feels, to paraphrase Bill Neidjie.

We are incapable of experiencing this natural empathetic dream-time state of human consciousness if we feel no twinge when we see a tree being felled, or a fish caught on a line; and when we no longer thank the tree and the fish, or seek to avoid such destruction and waste in the first place, since we kill more trees and fish than we need to live simply, economically, and never at nature's expense.

From dream-time comes the aborigine's wisdom and first law. It is the same for all people who are in touch with the divinity in every tree, fish, and natural thing, including themselves and each other. But it is dangerous, if not difficult, to enter dreamtime in any place where Nature has been desacralized and desecrated, because the pain can be so intense. It is dangerous because it is extremely stressful to mind and body. To be so open to the world when there is no outer peace intensifies one's sense of anxie- 
ty rather than of inner peace. Injustice, disharmony, waste and wanton destruction arise from human ignorance. It is the wisdom of enlightened self-interest that recognizes the importance of obedience to the Law that Bill Neidjie so vividly details for his people who have lived for some 50,000 years in civilized harmony with their environment.

As the lKung bushmen see it, we are all part of the same dream that is dreaming us (i.e., of the same creation). We destroy this dream when we do not live according to the Law.

The reality of dream-time is difficult for non-native westerners to comprehend. Poet Rainer Marie Rilke in the Duino Elegies comes close to it, referring to it as the invisible. He observes:

Transitoriness is everywhere plunging into profound Being . . . Nature, the things we move about among and use are provisional and perishable; but so long as we are here, they are our possession and our friendship, sharers in our trouble and gladness, just as they have been the confidants of our ancestors. Therefore, not only must all that is here not be corrupted or degraded, but, just because of that very provisionality they share with us, all these appearances and things should be comprehended by us in a most fervent understanding and transformed. Transformed? Yes, for our task is to stamp this provisional, perishing earth into ourselves so deeply, so painfully and passionately, that its being may rise again "invisibly" in us.

In other words, we must consciously become part of the dream that is dreaming us all, or at least obey the Law, even if we do not apprehend its source and wisdom. This is the path to world peace, the way of beauty, justice, humility, compassion and love. Lao Tzu called this quite simply, Tao. And the Iaw of the Tao for all civilizations is to respect that the loving harmony of humanity and Nature (symbolized in the embrace of $y$ in and yang) is the way of fulfillment for the whole of creation-and for the "Dreamer of the dream that is dreaming us" everywhere.

\section{Notes}

1. In Kadaku Man (N.S.W. Australia: Mybrood P/L, Inc., 1985).

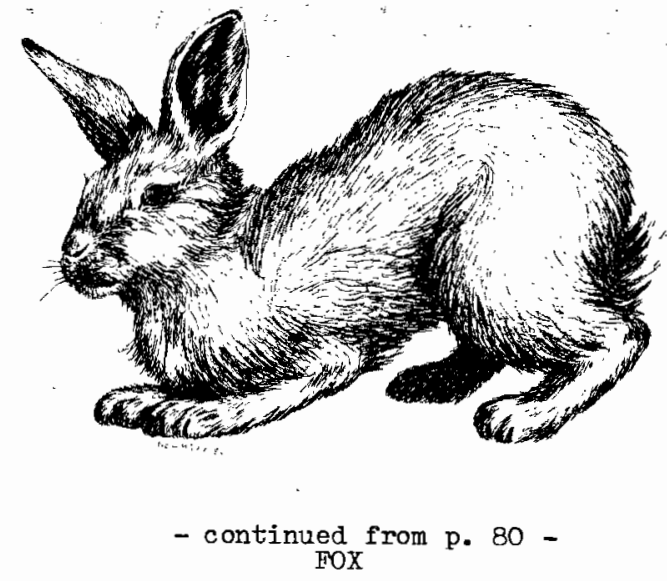

2. Jerrold Tannenbaum, Review of Michael Allen Fox, The Case for Animal Experimentation, The Scientist 1 (Oct 20, 1986): 19, 22.

3. Robert E. Goodin, "Ethical Principles for Environmental Protection," in Robert Ejliot and Arron Gare, eds., Environmental Philosophy (University Park: Pennsylvania State UniversityPress, 1983): 15 (author's emphasis).

4. Charles Fried, Right and Wrong (Cambridge: Harvand University Press, 1978): 30.

5. Tom Regan, The Case for Animal Rights (Berkeley: University of California Press, 1983).

6. To deliberately cause harm to others with no desire for personal gain is pure maliciousness and evil. To deliberately cause harm with the sole intent of benefiting from another's suffering is using another as a mere means to one's own ends and is at least as evil. One can think of examples where it is not wrong to benefit from another's suffering, but these would generally have to do with self-defense or self-protection.

7. The quotations are from Albert Schweitzer, Civilization and Ethics (The Philosophy of Civilization, Part III), 2nd ed., trans. C. T. Campion (Iondon: A. \& C. Black, 1929): 260, 264, and My Life and Thought, trans. C. T. Campion (London: A. Y C. Black, 1933): 271.

8. John Passmore, Man's Responsibility for Nature: Ecological Prablems and Western Traditions, 2nd ed. (London: Duckworth, 1980): 84. 